\title{
FoliaPrimatologica
}

No. 1

\section{Reviewed Articles}

1 The Short-Term Effects of a Hurricane on the Diet and Activity of Black Howlers (Alouatta pigra) in Monkey River, Belize

Behie, A.M.; Pavelka, M.S.M. (Calgary)

10 Two Breeding Females within Free-Living Groups May Not Always Indicate Polygyny: Alternative Subordinate Female Strategies in Common Marmosets (Callithrix jacchus)

Arruda, M.F.; Araújo, A.; Sousa, M.B.C.; Albuquerque, F.S.; Albuquerque, A.C.S.R.; Yamamoto, M.E. (Rio Grande do Norte)

21 Certain Aspects of Bonobo Female Sexual Repertoire Are Related to Urinary Testosterone Metabolite Levels

Sannen, A.; Van Elsacker, L. (Antwerp); Heistermann, M. (Göttingen); Eens, M. (Antwerp)

Brief Reports

33 Age-Related Variation in Copulations of Male Northern Muriquis (Brachyteles hypoxanthus) Possamai, C.B.; Young, R.J. (Minas Gerais); de Oliveira, R.C.R. (Minas Gerais/Nazaré Paulista); Mendes, S.L. (Vitoria); Strier, K.B. (Madison, Wisc.)

37 Testes Size and Body Weight in the Milne-Edwards' Sifaka (Propithecus edwardsi) of Ranomafana National Park, Madagascar, Relative to Other Strepsirhine Primates Pochron, S.T.; Wright, P.C. (Stony Brook, N.Y.)

\section{Book Reviews}

\section{Abstracts}

45 5th Meeting of the Spanish Primatological Society Valencia, September 16-20, 2003

Guest Editor: Guillén-Salazar, F. (Valencia)
No. 2

Reviewed Articles

67 Following the Rules: Why Small Groups of Tamarins Do Not Reconcile Conflicts

Schaffner, C.M. (Chester); Aureli, F. (Liverpool); Caine, N.G. (San Marcos, Calif.)

77 Schultz's Unruly Rule: Dental Developmental Sequences and Schedules in Small-Bodied, Folivorous Lemurs

Godfrey, L.R. (Amherst, Mass.); Samonds, K.E.; Wright, P.C. (Stony Brook, N.Y.); King, S.J. (Amherst, Mass.)

100 Red Colobus as Prey: The Leaping Habits of Five Sympatric Old World Monkeys Stern, M.; Goldstone, R. (Cambridge, Mass.)

Brief Reports

113 Predation of an Infant Titi Monkey (Callicebus moloch) by a Tufted Capuchin (Cebus apella) Sampaio, D.T.; Ferrari, S.F. (Belém)

116 A Novel Foraging Technique Observed in Slender Loris (Loris lydekkerianus malabaricus) Feeding on Red Ants in the Western Ghats, India Kumara, H.N.; Kumar, S.; Singh, M. (Mysore)

119 Termite Soil Eating in Kirindy Sifakas (Madagascar): Proposing a New Proximate Factor Norscia, I.; Carrai, V.; Ceccanti, B.; Borgognini Tarli, S.M. (Pisa)

\section{Book Review}

\section{KARGER}

Fax +41613061234 E-Mail karger@karger.ch www.karger.com
(C) 2005 S. Karger AG, Basel

Access to full text and tables of contents, including tentative ones for forthcoming issues: www.karger.com/fpr_issues 
No. 3

Original Articles

125 Colour Discrimination in the Black-Tufted-Ear Marmoset (Callithrix penicillata): Ecological Implications

Pessoa, D.M.A.; Cunha, J.F.; Tomaz, C.; Pessoa, V.F. (Brasilia)

135 Primate Population Densities in Three Nutrient-Poor Amazonian Terra Firme Forests of South-Eastern Colombia

Palacios, E. (Bogotá); Peres, C.A. (Norwich)

146 New Fossil Platyrrhine from Argentina Tejedor, M.F. (Esquel)

151 A Comparative Study of Adult Facial Morphology and its Ontogeny in the Fossil Macaque Macaca majori from Capo Figari, Sardinia, Italy Rook, L. (Firenze); O’Higgins, P. (Heslington)

Brief Reports

172 Extra-Unit Sexual Behaviour among Wild Sichuan Snub-Nosed Monkeys (Rhinopithecus roxellana) in the Qinling Mountains of China

Zhao, D.; Li, B.; Li, Y. (Xi'an); Wada, K. (Inuyama)

177 Occurrence of Infanticide among Wild Proboscis Monkeys (Nasalis larvatus) in Sabah, Northern Borneo Agoramoorthy, G. (Pingtung); Hsu, M.J. (Kaohsiung)

180 Use and Manufacture of Tools to Extract Food by Captive Gorilla gorilla gorilla: Experimental Approach

Pouydebat, E. (Paris/Toulon); Berge, C. (Paris); Gorce, P. (Toulon); Coppens, Y. (Paris)

\section{Book Review}

No. 4

\section{Original Articles}

185 Habitat Quality and Range Use of White-Headed Langurs in Fusui, China

Li, Z. (Kunming); Rogers, M.E. (Edinburgh)

196 Behavioral Development of Captive Male Hybrid Cercopithecine Monkeys

Erhart, E.M. (San Marcos, Tex.); Bramblett, C.A.; Overdorff, D.J. (Austin, Tex.)

207 Impact of Methodological Choices on Assessments of the Reliability of Fossil Primate Phylogenetic Hypotheses

Nadal-Roberts, M. (Palma de Mallorca); Collard, M. (Vancouver/London)

222 Chimpanzees Use Tools to Harvest Social Insects at Fongoli, Senegal

McGrew, W.C. (Oxford, Ohio); Pruetz, J.D. (Ames, Iowa); Fulton, S.J. (Oxford, Ohio)
Brief Reports

227 Hand-Holding by Belizean Black Howler Monkeys: Intentional Communication in a Neotropical

Primate

Brockett, R.C. (Belmopan); Horwich, R.H

(Gays Mills, Wisc.); Jones, C.B. (Fayetteville, N.C.)

231 Age-Dependent Activity Patterns of Wild Male Japanese Monkeys (Macaca fuscata yakui) on Yakushima Island

Merkle, T.F.C. (Bonn/Seewiesen)

234 Eye Preferences in Red-Capped Mangabeys Nedellec-Bienvenue, D.; Blois-Heulin, C. (Paimpont)

238 Cytogenetic Study of Lepilemur microdon Andriaholinirina, N. (Tananarive); Rabarivola, C. (Majunga); Hauwy, M.; Rumpler, Y. (Strasbourg)

242 Altruism or Cooperation in Captive Chimpanzees, Pan troglodytes?

Bethell, E.J. (London/Portsmouth); Waller, B.M. (Portsmouth)

No. 5

Original Articles

245 Shape of the Lateral Mandibular Outline in Lemuridae: A Quantitative Analysis of Variability Using Elliptical Fourier Analysis

Raveloson, H.; Le Minor, J.-M.; Rumpler, Y.;

Schmittbuhl, M. (Strasbourg)

262 Anatomy of the Hand and Arm in Daubentonia madagascariensis: A Functional and Phylogenetic Outlook

Soligo, C. (London)

301 Book Review

No. 6

Original Articles

303 Artificial Neural Networks and Three-Dimensional Digital Morphology: A Pilot Study

King, R.L. (Mississippi State, Miss.); Rosenberger, A.L.

(New York, N.Y.); Kanda, L.L. (Amherst, Mass.)

325 Dental Microwear Variability on Buccal Tooth Enamel Surfaces of Extant Catarrhini and the Miocene Fossil Dryopithecus laietanus (Hominoidea)

Galbany, J.; Moyà-Solà, S.; Pérez-Pérez, A. (Barcelona)

342 The Impact of Geophagy on Ranging Behaviour in Phayre's Leaf Monkeys (Trachypithecus phayrei) Pages, G.; Lloyd, E.; Suarez, S.A. (Stony Brook, N.Y.)

347 Author Index Vol. 76, 2005

350 Subject Index Vol. 76, 2005 